\title{
RE-EXAMINING ANOMALOUS EARLY DATES OF SETTLEMENT IN LEEWARD HAWAI'I ISLAND
}

\author{
Mike T Carson \\ Visiting Scholar, Department of Archaeology and Natural History, The Australian National University, Canberra, Australian \\ Capital Territory (ACT) 0200, Australia. Email: michael.carson@anu.edu.au.
}

\begin{abstract}
Anomalous dates prior to $1000 \mathrm{yr}$ BP have been reported for near-surface site deposits at Puapua'a in the dry and rocky zone of leeward (west) Hawai'i Island, compared to archipelago-wide earliest cultural layers generally in buried contexts $1000-800 \mathrm{yr}$ BP. Redating and closer examination cannot validate these early dates in cultural association. In the thin sedimentary deposits, preserved cultural materials mostly postdate $600-400 \mathrm{yr} \mathrm{BP}$, but some older materials were incorporated into the layer matrix. The results suggest a much shorter extant chronology of human settlement of this particular zone, whereas earliest sites most likely are preserved in different settings of the Hawaiian Islands.
\end{abstract}

\section{INTRODUCTION}

Potentially early dates of Hawaiian settlement deserve a closer examination to clarify their context at 2 sites in Puapua'a of leeward (west) Hawai'i Island (Figure 1). At the margins of East Polynesia, the first successful settlement of the Hawaiian Archipelago is estimated 1000-800 yr BP (Weisler 1989; Carson 2006; Kirch and McCoy 2007; McCoy 2007; Kirch 2011), congruent with East Polynesian settlement generally following 1100-1000 yr BP (Spriggs and Anderson 1993).

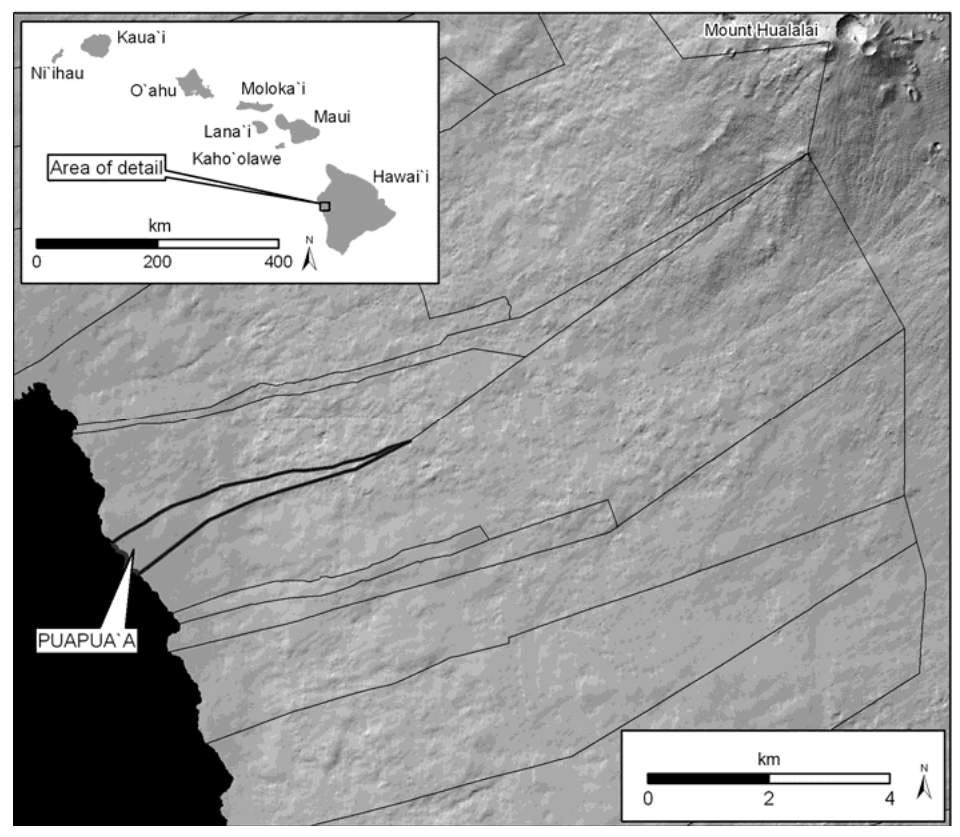

Figure 1 Puapua'a study area in leeward Hawai'i Island

One of the few areas producing radiocarbon dates of $1000 \mathrm{yr}$ BP or earlier for Hawaiian settlement is the ahupua 'a (traditional land unit) of Puapua'a in the Kona District of leeward Hawai'i Island. As discussed by Cordy (2000) and Kirch (2010), this dry and rocky zone generally is considered unfavorable compared to other settings with greater rainfall and more productive soils, yet leeward Hawai'i Island became one of the origin points of powerful political economies and perhaps an 
archaic state around 600-400 yr BP. In practical terms, early cultural layers are unlikely to be preserved in the shallow silts over bedrock, where they have been subjected to later natural and cultural disturbances.

A reconsideration of early dating in Puapua'a can be instructive not only for Hawaiian archaeology but generally for any study of similarly brief chronology less than $1000 \mathrm{yr}$. Within these short-lived parameters, ${ }^{14} \mathrm{C}$ dating is not always capable of discerning specific cultural periods. Additionally, site deposits tend to be rather shallow and to some degree intermixed, exacerbated in the constrained space of an island encouraging reuse and reworking of the same sites over some centuries. Preserved cultural layers do exist in rare stratified deposits, but most occurrences are undifferentiated single sedimentary layers.

The archaeological landscape at Puapua'a consists almost entirely of surface-visible stonework ruins with shallow deposits over basalt bedrock (Figure 2). The widespread architectural ruins represent overlays and reworkings over the course of some centuries, last used in the early AD 1800s. If ancient site deposits exist here, then they have been obscured and to some extent disturbed by the later occupations.

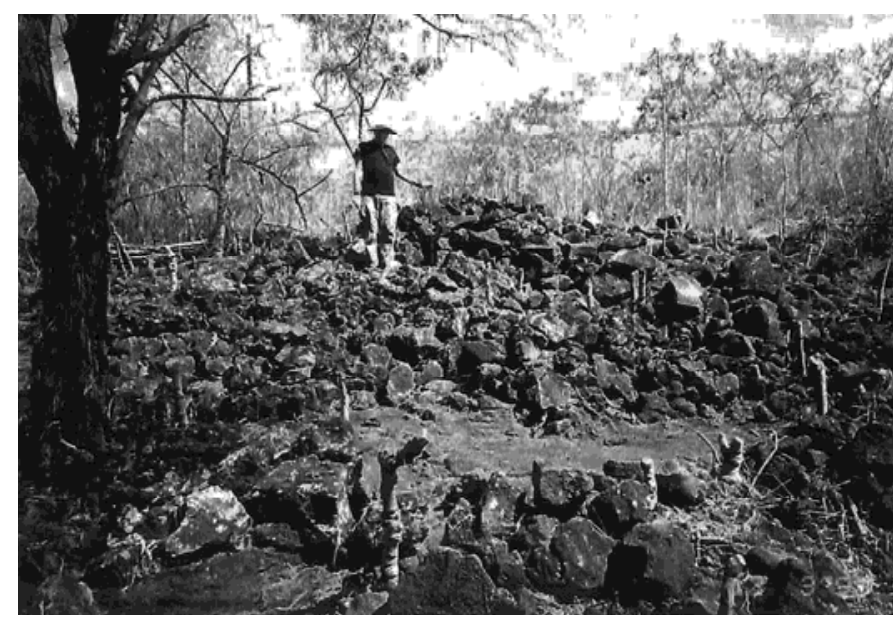

Figure 2 Stonework ruins at Site -9961 in Puapua‘a, Hawai'i Island

The present case study in Puapua'a accounts for new excavation results and redating of key samples at 2 sites (Table 1; see Figure 1). Taxonomic identification of wood charcoal specimens allowed assessment of short-lived specimens for the most confident dating, thanks to Gail Murakami at the Pacific Wood Identification Laboratory in Honolulu. The dating results were recalibrated with the current IntCal09 data set (Reimer et al. 2009), using OxCal software v 4 (Bronk Ramsey 2009).

\section{SITE 50-10-37-9961}

At Site -9961, an exceptionally early date of $2060 \pm 80 \mathrm{yr}$ BP (Beta-125942) was obtained for preserved grass inside a matrix of volcanic ash, contained within an effective sediment trap of a natural depression in the underlying basalt bedrock (Figure 3). In a $2 \times 2 \mathrm{~m}$ excavation (Carson 1999), the ash yielded no artifacts or midden. A superimposed silty layer similarly contained no artifacts or midden, but it was associated with the surface-visible stonework ruins of the site. 
Table 1 Re-assessment of Puapua'a potentially early ${ }^{14} \mathrm{C}$ dating results.

\begin{tabular}{|c|c|c|c|c|}
\hline Site and reference & $\begin{array}{l}\text { Lab sample } \\
\text { code }\end{array}$ & $\begin{array}{l}\text { Conventional } \\
{ }^{14} \mathrm{C} \text { age } \\
(\mathrm{yr} \mathrm{BP})\end{array}$ & $\begin{array}{l}\text { Calibrated age } \\
2 \sigma\end{array}$ & Comments \\
\hline $\begin{array}{l}\text { Site }-9961 \\
\text { (Carson 1999) }\end{array}$ & Beta-125942 & $2060 \pm 80$ & 356 BC-AD 121 & Noncultural volcanic ash \\
\hline $\begin{array}{l}\text { Site }-9962 \\
\text { (Landrum et al. 1990) }\end{array}$ & Beta-13252 & $1310 \pm 70$ & AD 613-883 & $\begin{array}{l}\text { Ash lens, no cultural mate- } \\
\text { rial }\end{array}$ \\
\hline $\begin{array}{l}\text { Site }-9962 \\
\text { (Carson 1999) }\end{array}$ & Beta-125940 & $1020 \pm 60$ & AD 894-1157 & $\begin{array}{l}\text { Charcoal in hearth feature, } \\
\text { incompatible with redating }\end{array}$ \\
\hline $\begin{array}{l}\text { Site }-9962 \\
\text { (new data) }\end{array}$ & Beta-217778 & $180 \pm 50$ & AD 1647-1953 & $\begin{array}{l}\text { Probable bottle gourd char- } \\
\text { coal in primary cultural layer }\end{array}$ \\
\hline $\begin{array}{l}\text { Site }-9962 \\
\text { (new data) }\end{array}$ & Beta-223729 & $270 \pm 40$ & AD 1486-1951 & $\begin{array}{l}\text { Probable bottle gourd char- } \\
\text { coal in hearth feature }\end{array}$ \\
\hline $\begin{array}{l}\text { Site }-9962 \\
\text { (new data) }\end{array}$ & Beta-223728 & $370 \pm 40$ & AD $1446-1635$ & $\begin{array}{l}\text { Probable bottle gourd char- } \\
\text { coal in hearth feature }\end{array}$ \\
\hline
\end{tabular}

${ }^{a}$ Calibrated at $2 \sigma$ range by OxCal v 4 (Bronk Ramsey 2009) and using IntCal09 data set (Reimer et al. 2009).

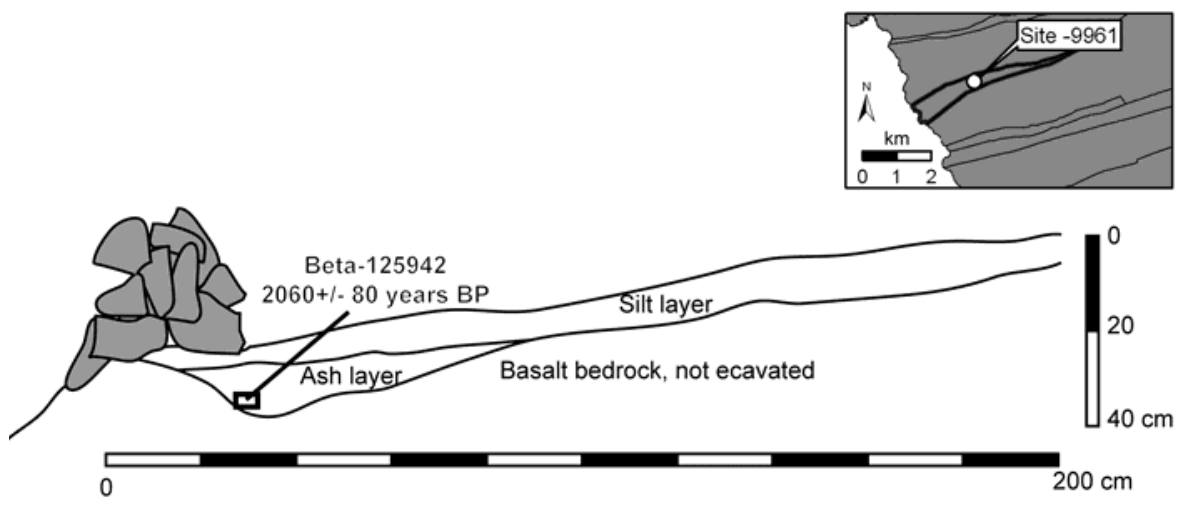

Figure 3 North excavation profile at Puapua'a Site -9961

The early dating at Site -9961 is from a noncultural origin, but it demonstrates the potential for old plant material to survive in thin deposits. The material in this case was short lived and did not incorporate an inbuilt old age per se. In other similar occurrences, the early plant material conceivably could become mixed into a much later context at any point during centuries of reworking the shallow rocky silts.

The volcanic event represented at Site -9961 was one of several such incidents affecting Puapua'a and the Kona District generally. Over the last few thousand years, numerous lava flows and ash-falls issued from the nearby Mount Hualalai that overlooks much of the Kona District (Wolfe and Morris 1996). The last recorded lava flow occurred in AD 1801 (Macdonald et al. 1983:364).

\section{SITE 50-10-37-9962}

At Site -9962, the first reported test pits (Landrum et al. 1990) noted an ash lens that yielded a conventional ${ }^{14} \mathrm{C}$ age of $1310 \pm 70 \mathrm{yr} \mathrm{BP}$ (Beta-13252). The nature of the ash was not specified as comprised of volcanic material or burned plant matter. It did not contain identifiable artifacts or midden. It appears possibly to have extended beneath the primary cultural layer of the site, and a cultural association is unclear. 
Just $2 \mathrm{~m}$ distant from the original test pits, a subsequent $3 \times 4 \mathrm{~m}$ excavation (Carson 1999) obtained a new date on a definite hearth feature associated with the cultural layer of Site -9962 (Figures 4 and 5 ). The hearth and the associated layer both contained utilized volcanic glass flakes, sea urchin spine abraders, edible shellfish remains, pig bone fragments, and other cultural materials typical of Hawaiian sites. A sample of charcoal from the hearth fill yielded a conventional ${ }^{14} \mathrm{C}$ age of $1020 \pm$ 60 yr BP (Beta-125940).

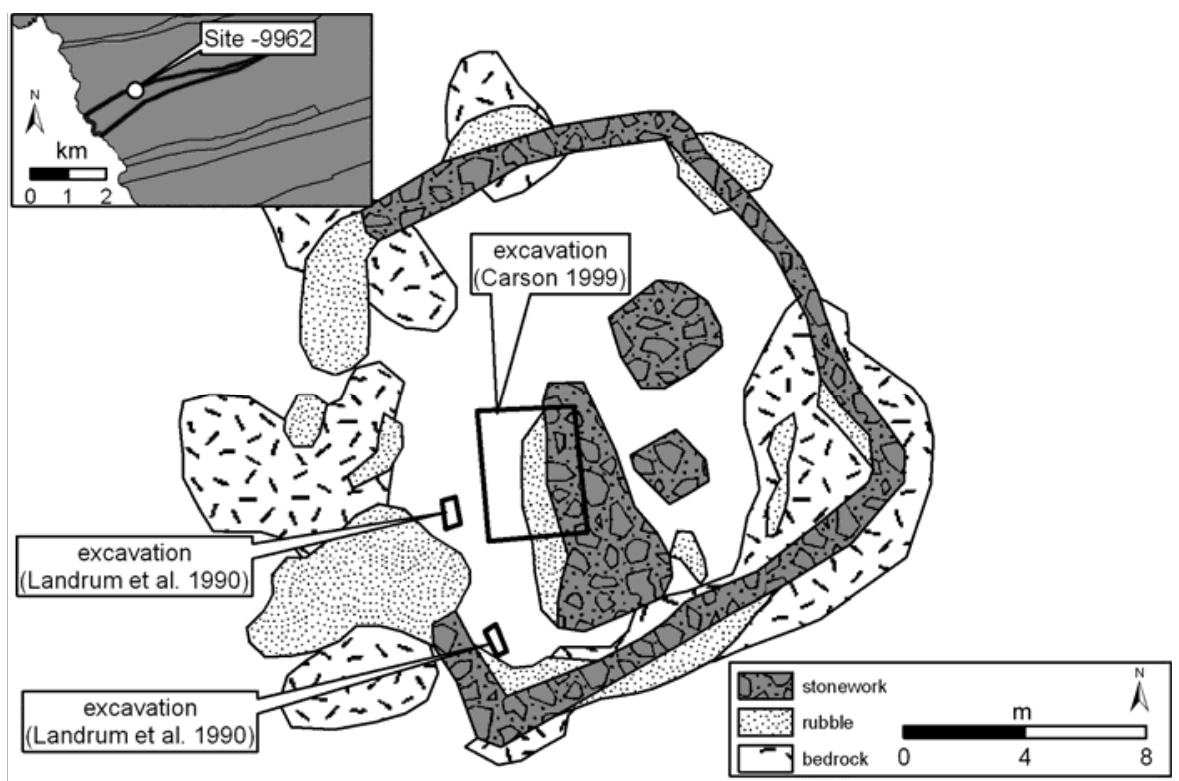

Figure 4 Plan of excavations at Puapua'a Site -9962

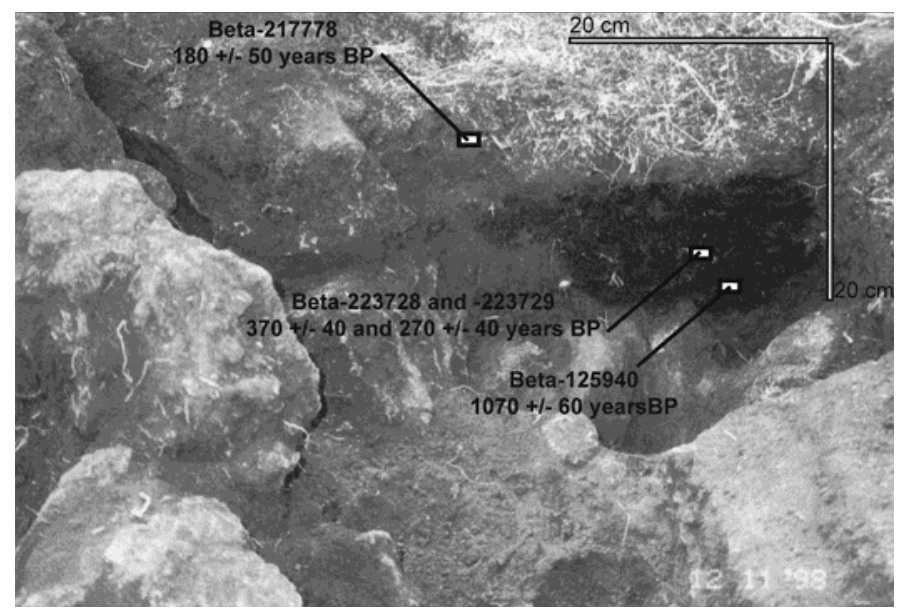

Figure 5 Section of hearth feature at Puapua'a Site -9962

An apparent age of $1000 \mathrm{yr}$ or earlier at Site -9962 at first seemed to confirm one of the earliest secure dates for settlement in the Hawaiian Archipelago. The dating was especially intriguing in this unlikely setting in Puapua'a. Upon further consideration, however, the dating results prompted 2 uncomfortable questions. 
The first uncomfortable question was about the represented date ranges of the original (Beta-13252) and later (Beta-125940) results. When calibrated at $2 \sigma$ (see Table 1), the results overlap during a few decades of the AD 800 s, but the likelihood of this overlap statistically is rather low. The earlier dating refers to an ash lens possibly beneath the cultural layer of the site, whereas the later dating refers to a hearth feature securely within the cultural layer. The 2 dating results cannot convincingly validate one another, and additional confirmatory dating would be necessary.

The second uncomfortable question was concerning the possibility that the hearth feature may have contained anomalously early "background" material predating the cultural layer. The very early date of preserved grass in a volcanic ash deposit at Site -9961 (2060 $\pm 80 \mathrm{yr}$ BP for Beta-125942) was obtained approximately $100 \mathrm{~m}$ upslope from Site -9962. Other volcanic activity may have contributed noncultural charcoal later mixed into the hearth feature at Site -9962. Similarly, the possibility exists that an inbuilt old age of driftwood or an old-growth tree could create an "old wood" effect of 100 or more years (Dye 2000).

The most reasonable means to resolve dating of Site -9962 was to obtain additional dates for identified short-lived and definitely anthropogenic wood charcoal specimens in the hearth feature and associated cultural layer. Samples retained from the 1998 excavation (Carson 1999) were examined by wood anatomist Gail Murakami at the Pacific Wood Identification Laboratory in 2006.

The charcoal samples were identified as carbonized pieces of breadfruit wood (Artocarpus altilis), probable bottle gourd (Lagenaria siceraria), and others not clearly recognizable. Breadfruit (A. altilis) was an important tree crop imported from elsewhere in Polynesia (McCoy et al. 2010). The bottle gourd (L. siceraria) possibly was translocated from the Americas (Clarke et al. 2006).

The fragments of probable bottle gourd were considered to represent short-lived and human-introduced specimens most appropriate for ${ }^{14} \mathrm{C}$ dating. Two fragments from the hearth feature produced conventional ${ }^{14} \mathrm{C}$ ages of $370 \pm 50 \mathrm{yr}$ BP (Beta-223728) and $270 \pm 40 \mathrm{yr}$ BP (Beta-223729). An additional fragment from the upper limit of the associated cultural layer yielded a conventional ${ }^{14} \mathrm{C}$ age of $180 \pm 50 \mathrm{yr}$ BP (Beta-217778).

The redating of Site -9962 conclusively shows that the hearth feature postdates $400 \mathrm{yr}$ BP, and the upper portion of the associated cultural layer postdates $200 \mathrm{yr}$ BP. These results entirely contradict the prior dating of $1070 \pm 60 \mathrm{yr}$ BP for the hearth (Beta-125940), and they even further diverge from the dating of the nearby ash lens at $1310 \pm 70 \mathrm{yr}$ BP (Beta-13252).

\section{CONCLUSIONS}

The details for sites -9961 and -9962 reveal that ${ }^{14} \mathrm{C}$ dates of $1000 \mathrm{yr}$ BP or earlier in these cases do not refer to cultural activities, but instead they refer to older noncultural events. This caution can apply generally to the Kona District of leeward Hawai'i Island, but it does not necessarily apply to the archipelago as a whole. It is most relevant for areas of shallow sedimentary deposits as described here.

The present work supports the expectation that earliest settlement around $1000-800 \mathrm{yr} \mathrm{BP}$ is unlikely to be found in rocky terrain such as Puapua'a, but rather sites postdating 600-400 yr BP are by far the most numerous. An island-wide ${ }^{14} \mathrm{C}$ review confirms this same pattern (Rieth et al. 2011), but most of these dates were obtained from inland areas, rocky terrain, and dry leeward zones. The best opportunities for finding earliest occupation layers are in preserved deep beach sites (Carson 2004). In contrast, the vast majority of Hawaiian archaeological study has transpired in settings most unlikely to yield earliest dates, where thin silts and clays overlay volcanic bedrock. 
These cautionary parameters may apply to other research of similarly brief cultural chronology within the last 1000 yr. Not only in Hawai'i but generally in Pacific Island settings, most archaeological surveys concern landward or inland zones with little opportunity for deeply stratified ancient site deposits. Given the geological age of most inland terrain, opportunities exist for naturally old material to become incorporated into later cultural layers, but only the more recent cultural remnants are preserved in the best condition today.

\section{ACKNOWLEDGMENTS}

This manuscript was prepared while the author was a visiting scholar at the Australian National University (RSAP grant scheme, project 23714). The study began as part of a project directed by the author in 1998-99 while employed at Scientific Consultant Services (SCS). Thanks are due to Michael F Dega and Robert L Spear at SCS for making the field collections available for further analysis in 2006. Thanks also are due to Gail Murakami at Pacific Wood Identification Laboratory in Honolulu for identifying the wood charcoal fragments. The author used personal funds for the 2006 redating of 3 samples by Beta Analytic, Inc.

\section{REFERENCES}

Bronk Ramsey C. 2009. Bayesian analysis of radiocarbon dates. Radiocarbon 51(1):337-60.

Carson MT. 1999. Data recovery at the Phase I portion of the Kahakai Development Project Area, Puapua'a 1st and 2nd, North Kona District, Hawai'i Island, State of Hawaii (TMK 3-7-5-20:1). Report prepared for Stanford Carr Development, Inc. Honolulu: Scientific Consultant Services.

Carson MT. 2004. Resolving the enigma of early coastal settlement in the Hawaiian Islands: the stratigraphic sequence of the Wainiha Beach Site in Kaua'i. Geoarchaeology 19(2):99-118.

Carson MT. 2006. Chronology in Kaua'i: colonisation, land use, demography. Journal of the Polynesian Society 115(2):173-85.

Clarke AC, Burtenshaw MK, McLenachan PA, Erickson DL, Penny D. 2006. Reconstructing the origins and dispersal of the Polynesian bottle gourd (Lagenaria siceraria). Molecular Biology and Evolution 23(5): 893-900.

Cordy R. 2000. Exalted Sits the Chief: The Ancient History of Hawai 'i Island. Honolulu: Mutual Publishing.

Dye TS. 2000. Effects of ${ }^{14} \mathrm{C}$ sample selection in archaeology: an example from Hawaii. Radiocarbon 42(2): 203-17.

Kirch PV. 2010. How Chiefs Became Kings: Divine Kingship and the Rise of Archaic States in Ancient Hawai ' $i$. Berkeley: University of California Press.

Kirch PV. 2011. When did the Polynesians settle Hawaii? A review of 150 years of scholarly inquiry and a tentative answer. Hawaiian Archaeology 12:3-26.

Kirch PV, McCoy MD. 2007. Reconfiguring the Hawaiian cultural sequence: results of re-dating the Hālawa Dune Site (MO-A1-3), Moloka'i Island. Journal of the Polynesian Society 116(4):385-406.

Landrum J, Haun AE, Rosendahl PH. 1990. Archaeological inventory survey and test excavations, Kahakai
Development Project Area, lands of Puapua'a 1st and 2nd, North Kona, Island of Hawaii (TMK:3-7-5-20: 1). Report prepared for $\mathrm{KG}$ Hawaii Construction. Hilo: Paul H. Rosendahl, PhD, Inc.

Macdonald GA, Abbott AT, Peterson FL. 1983. Volcanoes in the Sea: The Geology of Hawaii. 2nd edition. Honolulu: University of Hawaii Press.

McCoy MD. 2007. A revised late Holocene culture history for Moloka'i Island, Hawai'i. Radiocarbon 49(3): 1273-322.

McCoy MD, Graves MW, Murakami G. 2010. Introduction of breadfruit (Artocarpus altilis) to the Hawaiian Islands. Economic Botany 64(4):374-81.

Reimer PJ, Baillie MGL, Bard E, Bayliss A, Beck JW, Blackwell PG, Bronk Ramsey C, Buck CE, Burr GS, Edwards RL, Friedrich M, Grootes PM, Guilderson TP, Hajdas I, Heaton TJ, Hogg AG, Hughen KA, Kaiser KF, Kromer B, McCormac FG, Manning SW, Reimer RW, Richards DA, Southon JR, Talamo S, Turney CSM, van der Plicht J, Weyhenmeyer CE. 2009. IntCa109 and Marine09 radiocarbon age calibration curves, 0-50,000 years cal BP. Radiocarbon 51(4): 1111-50.

Rieth TM, Hunt TL, Lipo C, Wilmshurst JM. 2011. The 13th century Polynesian colonization of Hawai'i Island. Journal of Archaeological Science 38(10):27409.

Spriggs M, Anderson A. 1993. Late colonization of East Polynesia. Antiquity 67:200-27.

Weisler MI. 1989. Chronometric dating and late Holocene prehistory in the Hawaiian Islands: a critical review of radiocarbon dates from Moloka'i Island. $R a$ diocarbon 31(2):121-45.

Wolfe EW, Morris J. 1996. Geologic map of the island of Hawaii. Washington, DC: US Department of the Interior, US Geological Survey. 